\title{
The effects of the "green passive MAP" on the evolution of the gaseous and quality parameters in strawberries
}

\author{
Briano R, Peano C, Giuggioli N.R \\ Department of Agricultural, Forest and Food Sciences, University of Torino, Largo Paolo Braccini 2, Grugliasco (TO) 10095, Italy
}

\section{A B S T R A C T}

\begin{abstract}
The strawberries having an high perishability are more likely off-flavor during the postharvest. The control of volatile composition and quality of fruits during the postharvest handling is important especially in response to the change of the storage temperature. The objective of this study was to evaluate the effect of "green" passive MAP using films from natural sources on the evolution of the most important gaseous and quality maturity indices for the strawberries fruits cv. Portola under the changes of the storage temperature. Strawberries of cv. Portola were packaged with polypropylene (PP) film used as control, polylactic acid (PLA) and a prototype of non-commercial biodegradable and compostable film (BIO N.C.) up to 10 days. Fruits were maintained at $+2{ }^{\circ} \mathrm{C}$ for 7 days and then were shifted at +20 ${ }^{\circ} \mathrm{C}$ for shelf life. The highest fermentative metabolites as aldehyde, ethanol and ethyl acetate (respectively $0.013 \mu \mathrm{l} / \mathrm{l}, 2.560 \mu \mathrm{l} / \mathrm{l}$ and $0.830 \mu \mathrm{l} / \mathrm{l})$ was detected at the end of storage into the PLA due to the highest $\mathrm{CO}_{2}(41.4 \mathrm{kPa})$ and the lowest $\mathrm{O}_{2}(2.7 \mathrm{kPa})$ concentrations achieved into the MAP. Strawberries stored with the PP and BIO N.C. MAPs globally showed the best qualitative parameters.
\end{abstract}

Keywords: cv. Portola; Flexible packaging; Off-flavor; Post harvest quality; Temperature

\section{INTRODUCTION}

According to the current social and economic scenario the driver of the innovation in the management of freshness and quality of perishable fruits such as strawberry is the sustainability requirement. The traditional post harvest techniques used until now need to be improved meeting the request of a greener supply chain system, consequently also the modified atmosphere packaging (MAP), that is well known to improve the shelf life of many fresh fruits and vegetables reducing their respiration rate (Kader and Barrett, 2005; Caner et al., 2008; Mangaraj et al., 2009; Soltani et al., 2015; Zang et al., 2015; Blanco-Diaz et al., 2016), must to be considered in this new prospective. The sustainability of the MAP technique to preserve fresh fruits is today mainly associated to the use on new materials (Almenar et al., 2008; Cagnon et al., 2013; Briano et al., 2015; Mistriotis et al., 2016) whose mechanical and chemical characteristics are well described (Cano et al., 2015), but more studies are necessary about their interaction with the contained fruits especially in terms of fermentative compounds, resulting by the post harvest maturity processes, that affect the acceptability of the consumers.
The goodness of the MAP is largely dependent by the cultivar, the storage temperature that affects the respiration rate of the fruits, the gas and the water permeability of the wrapping film. All these variables must be considered to evaluate the effect of this technique especially in the case of the strawberries supply chain whose critical point is the maintenance of low the temperature (Pelayo et al., 2003; Russel et al., 2009). The temperature is the driver of the most important postharvest maturity metabolisms of the strawberries and it is also influences the diffusion processes of the aroma, off-flavour and the gas index of maturity $\left(\mathrm{CO}_{2}\right.$ and $\left.\mathrm{O}_{2}\right)$ through the packaging material. The diffusion process of the main migrating substances and their adverse consequences for the acceptability of the food matrix are deeply studied for polymeric film of flexible packaging (Nielsen and Jagerstad, 1994; Sajilata et al., 2007; Ponce-Valadez and Watkins, 2008) but less information there are about the barrier performances to gas, aroma and off-flavor compounds of the green materials (Briano et al., 2015; Giuggioli et al., 2015) available for the MAP storage in the fruit supply chain. Anoxic condition due high $\mathrm{CO}_{2}(15-20 \mathrm{kPa})$ and low $\mathrm{O}_{2}$ levels inside MAP influence the activity of the enzyme alcohol

\footnotetext{
${ }^{*}$ Corresponding author:

Briano R, Department of Agricultural, Forest and Food Sciences, University of Torino, Largo Paolo Braccini 2, Grugliasco (TO) 10095 , Italy. E-mail: rossella.briano@unito.it
}

Received: 25 October 2016; Revised: 06 February 2017; Accepted: 07 February 2017; Published Online: 17 February 2017 
dehydrogenase $(\mathrm{ADH})$ and the relative accumulation of the main alcoholic off-flavor such as acetaldehyde, ethanol and methanol (Kennedy et al., 1992; Fernandez-Trujillo et al., 1999; Wani et al., 2014), so the new films for MAP should avoid these conditions.

The aim of this work was to evaluate the effect of "green" passive MAP using films from natural sources on the evolution of the most important gaseous and quality maturity indices for the strawberries fruits cv. Portola under the changes of the storage temperature.

\section{MATERIALS AND METHODS}

\section{Strawberry samples and storage conditions}

Strawberry fruits (Fragaria $x$ ananassa) cv. Portola were picked by hand from the commercial orchard (Agrifrutta Soc. Coop. S.r.l., Piedmond, Italy) directly in the basket and immediately transported to the cooperative cold storage room $\left(5 \pm 1^{\circ} \mathrm{C}\right.$ and $\left.80-85 \% \mathrm{RH}\right)$.

The fruits were selected in function of the uniformity of size, the external colour of the skin and free of external blemishes and damaging.

The passive modified atmosphere packaging (MAP) conditions were developed into baskets of L13.5x w9.0 x h2.5 cm after the packaging's process using a commercial flowpack machine (model Taurus 800, Delphin, Italy).

The films used for the experiment were all continuous packaging films. The PP (polypropylene) is the control (Trepack, Siena, Italy), the PLA (polilactid acid) is a commercial biodegradable film made from renewable resources (Nativia ${ }^{\circledR}$, Taghleeef Industries, Udine, Italy) and the last the BIO N.C. is a non-commercial biodegradable and compostable film (prototypes, Novamont, Novara, Italy). All films thickness were of $25 \mu \mathrm{m}$, the $\mathrm{CO}_{2}$ permeability was of $1.98 \mathrm{E}^{-12}, 1.34 \mathrm{E}^{-12}$ and $1.38 \mathrm{E}^{-12} \mathrm{mmol} \mathrm{cm} \mathrm{cm} \mathrm{h}^{-1} \mathrm{kPa}^{-1}$ respectively for the PP, PLA and BIO N.C. films while the $\mathrm{O}_{2}$ permeability was of $6.24 \mathrm{E}^{-13}, 3.21 \mathrm{E}^{-13}$ and $3.57 \mathrm{E}^{-13}$.

\section{Sampling preparation}

The strawberries were stored for 7 days at $2^{\circ} \mathrm{C}$ plus 3 days at $20^{\circ} \mathrm{C}$. At 0 (packing fruit), 3, 5, 7, 10 days of storage six packages per film type were evaluated: three were used to measure the gas composition, respiration rates and off-flavor, the other three to evaluated the other qualitative parameters.

\section{Measurement of $\mathrm{O}_{2}$ and $\mathrm{CO}_{2}$ partial pressure concentrations in MAP}

The gas measurements were sampled with a portable manual $\mathrm{CO}_{2}$ and $\mathrm{O}_{2}$ analyser (CheckPoint II, PBI Dansensor, Italy).
The values are an average of three replicates and were expressed as $\mathrm{v} / \mathrm{v} \mathrm{kPa}$. For each measurements the free volume of the package $(330 \mathrm{~mL})$ was keep unchanged during the storage time because the instrument introduced across an adhesive single septum system on the package's surface (Septum white $15 \mathrm{~mm}$ diameter, Dansensor, Italy) the same quantity of air that it removed for the analyses.

\section{Gaseous maturity index determination}

The determination of the $\mathrm{RRO}_{2}$ and $\mathrm{RRCO}_{2}$ and off-flavors (acetaldehyde, ethanol, ethyl acetate) $(\mu \mathrm{g} / \mathrm{l})$ respectively products of the respiration and the fermentative metabolisms of fruits were determined manually by injection of $50 \mu \mathrm{l}$ of gas onto an Agilent Varian 450 GC. A capillary column (Molsieve $5^{\circ}$ PLOT $30 \mu \mathrm{m}$ x $30 \mathrm{~m}$ x $0.53 \mathrm{~mm}$ ) and TCD detector (oven temperature of $70^{\circ} \mathrm{C}$; injector $140^{\circ} \mathrm{C}$ ) were used to measure the $\mathrm{O}_{2}$ and $\mathrm{CO}_{2}$ headspace gas composition while the off-flavor compounds were monitored using a DBWAX column $(30 \mathrm{~m}$ x $0.53 \mathrm{~mm}$ x $1 \mathrm{pm}$ ) and FID detector (oven temperature of $50^{\circ} \mathrm{C}$; injector $100^{\circ} \mathrm{C}$; detector $150^{\circ} \mathrm{C}$ for all the analysis).

$\mathrm{O}_{2}, \mathrm{CO}_{2}$, acetaldehyde, ethyl acetate and ethanol were detected on the basis of their retention times and quantified by using a range of standards of the compounds (in air).

The rates of $\mathrm{O}_{2}$ uptake $\left(\mathrm{RRO}_{2}\right)$ and $\mathrm{CO}_{2}$ production $\left(\mathrm{RRCO}_{2}\right)\left(\mathrm{mmol} \mathrm{kg}^{-1} \mathrm{~h}^{-1}\right)$ by strawberries in MAP were calculated respectively according to the Eq.1 and Eq.2

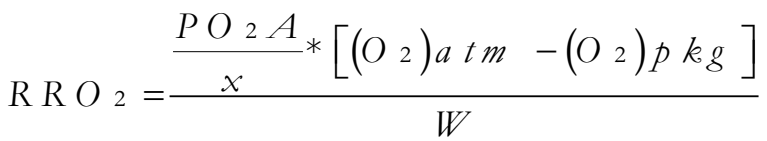

$$
\begin{aligned}
& \mathrm{RRCO} 2=\frac{\frac{P C \mathrm{O}_{2} A}{x} *\left[\left(\mathrm{CO}_{2}\right) p k g-\left(\mathrm{CO}_{2}\right) a t m\right]}{W}
\end{aligned}
$$

Where $\mathrm{PO}_{2}$ and $\mathrm{PCO}_{2}$ are the permeability coefficient $\left(\mathrm{mmol} \mathrm{cm} \mathrm{cm} \mathrm{c}^{-2} \mathrm{~h}^{-1} \mathrm{kPa}^{-1}\right)$; $\mathrm{A}$ is the film surface area $\left(\mathrm{cm}^{2}\right)$, $\mathrm{x}$ is the film thickness $(\mathrm{cm}), \mathrm{O}_{2 \mathrm{pkg}}$ and $\mathrm{CO}_{2 \mathrm{pkg}}$ are the gas concentration inside the package $(\mathrm{kPa}), \mathrm{O}_{2 \mathrm{~atm}}$ and $\mathrm{CO}_{2 \mathrm{~atm}}$ are the gas atmospheric partial pressure $(\mathrm{kPa})$ and $\mathrm{W}$ is the strawberries weight $(\mathrm{kg})$.

\section{Quality and nutraceutical measurements}

The strawberries pulp firmness was measured using a handheld penetrometer (Turoni, Forlì, Italy) with a 5-mm-diameter plunger and a reading scale of $\mathrm{N}$ in accordance with standard industry practice. The total soluble solids content (TSSC; ${ }^{\circ}$ Brix) was determined from each samples fruit (20 fruits) by squeezing a drop of juice onto a digital refractometer pocket refractometer (Atago Co. Ltd., Tokyo, Japan) calibrated at 
$20^{\circ} \mathrm{C}$ to $0 \%$ with distilled water. After, $5 \mathrm{ml}$ of the same juice was diluted with $25 \mathrm{ml}$ of distilled water to determine the titratable acidity (meq $\mathrm{l}^{-1}$ ) using an automatic titrator (Titrino 702, Metrohm, Herisau, Switzerland). The result expressed as $\%$ citric acid was calculated on the average of three measure/sample using a conversion factor following previous work (Bermejo-Prada and Otero, 2016).

The external color was measured using a portable colorimeter (Chroma Meter CR-400, Konica Minolta Sensing, Inc., Tokyo, Japan) using the CIELAB scale defined by the Commission International de L'Eclairage, in which L* (lightness/darkness), a* (redness/greenness) and $\mathrm{b}^{*}$ (yellowness/blueness) are mutually perpendicular axes. These parameters were considered to define the color index (CI) according to the following equation JiménezCuesta et al. (1981):

$$
C I=\frac{1000 * a}{L * b}
$$

To determine the total phenolic content, the strawberry extract was obtained by using $10 \mathrm{~g}$ of fruit added to $25 \mathrm{~mL}$ of extraction buffer $(500 \mathrm{~mL}$ methanol, $23.8 \mathrm{~mL}$ deionised water and $1.4 \mathrm{~mL}$ hydrochloric acid $37 \%$ ). After $1 \mathrm{~h}$ in the dark at room temperature, the samples were thoroughly omogenised for a few minutes with an Ultra Turrax (IKA, Staufen, Germany) and centrifuged for $15 \mathrm{~min}$ at $3000 \mathrm{rpm}$. The supernatant obtained by centrifugation was collected and transferred to glass test tubes and stored at $-20^{\circ} \mathrm{C}$ until analysis. The total phenolic contents were measured by using a Folin-Ciocalteu reagent with gallic acid as a standard at $765 \mathrm{~nm}$ following the method of Slinkard and Singleton (1977). The results are expressed as milligrams of gallic acid equivalents (GAE) per $100 \mathrm{~g}$ of fresh weight (F.W.) and were performed using a UV-Vis spectrophotometer (UV-1600PC, VWR International).

\section{Statistical analysis}

All statistical analyses were performed using the SPSS Statistics 20 statistical software package (SPSS Statistics
20, 2013, IBM, Italy) for Mac. The obtained data were subjected to two-way analysis of variance (ANOVA), and the means of the quality and nutraceutical parameters were separated using Duncan's test $(\mathrm{P} \leq 0.05)$.

A principal component analysis (PCA) with Varimax rotation with Kaiser normalization (SPSS 20.0) was entered to underline the relationships between the maturity index and the quality parameters of parameters measured. The PCA was performed using standardized data due the reduction of the dimensionality of the multivariate data.

\section{RESULTS AND DISCUSSION}

\section{$\mathrm{O}_{2}$ and $\mathrm{CO}_{2}$ concentrations in MAP}

The evolution of the partial pressures of the $\mathrm{CO}_{2}$ and $\mathrm{O}_{2}$ of the samples stored in MAP is shown in Fig. 1. The gas composition inside each package during the storage time is influenced by the interaction among environmental factors (storage temperature), physical characteristics of the films used for MAP (permeability properties and thickness) and physiological behavior of fruits (respiration rate).

For all samples a similar pattern of decrease in the $\mathrm{O}_{2}$ headspace gas composition and a $\mathrm{CO}_{2}$ increase over time was observed. For the strawberries stored at low temperature $\left(+2{ }^{\circ} \mathrm{C}\right)$, the $\mathrm{O}_{2}$ content decreased from the initial values of $3.0 \mathrm{kPa}, 22.0 \mathrm{kPa}$ and $28.0 \mathrm{kPa}$ respectively for the PP, PLA and BIO N.C film up to 5 days of storage while the $\mathrm{CO}_{2}$ content increased to $1.3 \mathrm{kPa}, 5.3 \mathrm{kPa}$ and $11.2 \mathrm{kPa}$ in the same time period (Fig. 1). At the highest temperature at 7 days of storage, the trend of both gas have followed the same tendency the $\mathrm{CO}_{2}$ content increased and $\mathrm{O}_{2}$ content decreased more quickly and more greatly. This behaviour is explained by the increase in the respiration activity of strawberries that is faster than the diffusion mechanisms of gas through the wrapping films. At the end of storage, the PLA films maintained the highest $\mathrm{CO}_{2}(41.4 \mathrm{kPa})$ and the lowest $\mathrm{O}_{2}(2.74 \mathrm{kPa})$ values due the lesser values of the gas permeability of the film if compared to the others.
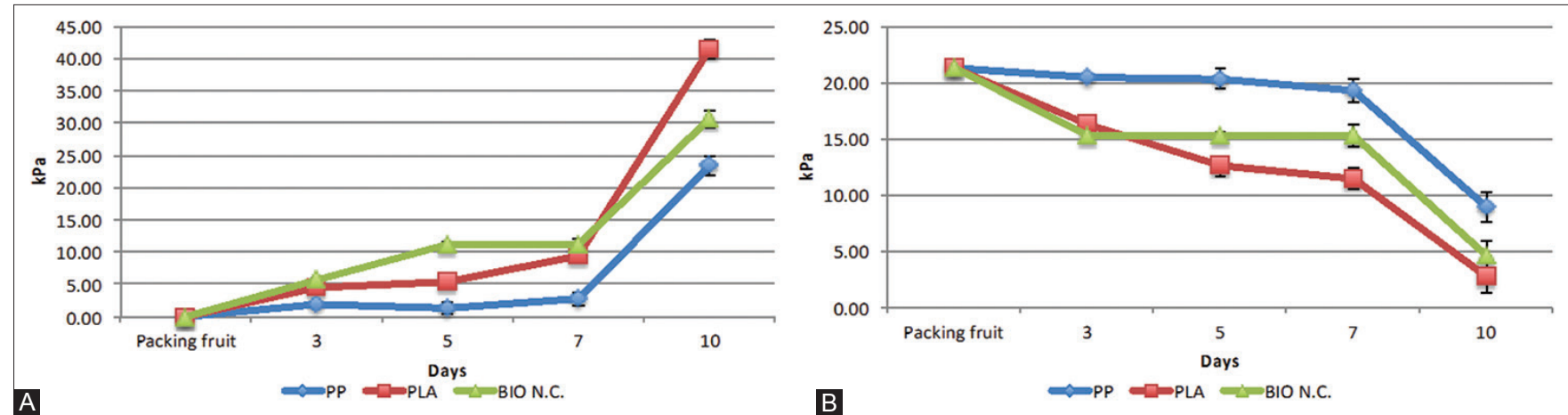

Fig 1. Evolution of $\mathrm{CO}_{2}$ partial pressure $(A)$ and $\mathrm{O}_{2}$ partial pressure (B) for PP, PLA and BIO N.C. films during all the storage. 


\section{Gaseous maturity index}

The $\mathrm{O}_{2}$ consumption and $\mathrm{CO}_{2}$ production rates of Portola strawberries were examined at different temperatures during the storage time under the different MAP conditions (Table1). Different studies (Li and Kader, 1989; Kader, 1991; Talasila et al., 1992; Renault et al., 1994; Hertog et al., 1999), reported the respiration rates of strawberries under different gas concentrations but no information are about the cv. Portola stored with the "green" films. The oxygen consumption of the strawberries (Table 1) increased with significantly statistical differences with the storage time and with the change of the temperature affecting respectively the headspace gas composition inside each packages (Fig. 1).

The oxygen consumption rates of strawberries at low temperature after 3 days of storage was of $1.74 \mathrm{E}^{-07}, 1.73 \mathrm{E}^{-06}$ and $1.48 \mathrm{E}^{-06} \mathrm{ml} \mathrm{kg}^{-1} \mathrm{~h}^{-1}$ respectively for the PP, PLA and BIO N.C. film and at the end of the storage time after 10 days they have been changed to $6.48 \mathrm{E}^{-06} ; 4.76 \mathrm{E}^{-06}$ and $8.12 \mathrm{E}^{-06} \mathrm{ml} \mathrm{kg}^{-1} \mathrm{~h}^{-1}$. For each time, no statistically differences were observed among the different films. The main volatile compounds that are low-molecular-weight are strongly related to the primary and secondary fruit metabolism and their control is important to judge how a postharvest technique is good (Sucan, 2004).

The acetaldehyde (AA), ethanol (ETOH) and ethyl acetate (EA) levels accumulated during the strawberries storage under MAP conditions are reported respectively in the Fig. 2A, 2B and 2C. In general, the concentrations of all volatile compounds increase after the samples were removed from the low temperature $\left(+2^{\circ} \mathrm{C}\right)$, but in the case of acetaldehyde this was observed already before the $7^{\text {th }}$ day when the temperature has been changed. Pesis et al. (1990) and Shaw et al. (1990) suggested as little increase of these esters compounds can improve the flavor development of strawberries, however high levels can negatively affect the sensory acceptability by the consumers (Watkins et al., 1991; Larsen and Watkins, 1995). It' s known that the acetaldehyde accumulation is in function of anaerobic storage conditions more than overripe stage of fruits but also controlled atmosphere $\left(21.0 \mathrm{kPa} \mathrm{O}_{2}\right.$ and $\left.50.0 \mathrm{kPa} \mathrm{CO}\right)$ greatly affect the highest acetaldehyde concentration (Ke et al., 1994). The acetaldehyde levels monitored during all the storage time have been resulted to be under the acceptable levels, that are suggested by Ke et al. (1991) to be $8.1 \mu \mathrm{l}^{-1}$. In fact all samples showed concentrations of acetaldehyde less than $0.020 \mu \mathrm{l}^{-1}$ and this conditions was observed also at the end of the storage time where the highest $\mathrm{CO}_{2}$ concentrations were achieved inside all the MAP (Fig. 1).

The pattern of ethanol accumulation in the MAPs was similar to that of AA. Ethanol was almost undetectable in all packages for all the storage time; the highest concentrations were observed after 10 days of storage with $1.403 ; 2.560$ and $0.627 \mu \mathrm{l} / 1$ respectively for PP, PLA and BIO N.C. films. About the ethyl acetate the highest concentrations were detected after 10 days of storage in the samples packaged with the PLA film but these levels according to Larsen and Watkins (1995) aren't judged negatively for the final consumer acceptance. Considering the AA, ETOH and EA content it can be observed that the presence of the highest fermentative metabolites was into the PLA packages; this was probably due to the highest $\mathrm{CO}_{2} \mathrm{kPa}$ (41.4) and the lowest $\mathrm{O}_{2} \mathrm{kPa}(2.7)$ concentrations achieved into the MAPs.

The ETOH was confirmed to be the highest volatile compounds detected according to previous studies (Ke et al., 1991; Ke et al., 1994).

\section{Quality measurements}

The most important monitored quality parameters are reported in the Table 2. At the packaging time (packing fruits) strawberries showed firmness of $4113.66 \mathrm{~N}$. All samples stored at the lowest temperature $\left(+2^{\circ} \mathrm{C}\right)$ showed an increase of values meaning fruits with harder pulp. This happens probably due to the effect of the cool temperature that impacts on the plasticity and turgidity

\begin{tabular}{|c|c|c|c|c|c|c|c|c|c|c|c|c|}
\hline Days & \multicolumn{3}{|c|}{3} & \multicolumn{3}{|c|}{5} & \multicolumn{3}{|c|}{7} & \multicolumn{3}{|c|}{10} \\
\hline Film/Storage temperature & \multicolumn{9}{|c|}{$2 \pm 1^{\circ} \mathrm{C}$} & \multicolumn{3}{|c|}{$20 \pm 1^{\circ} \mathrm{C}$} \\
\hline $\mathrm{RRCO}_{2}\left(\mathrm{ml} \mathrm{kg}{ }^{-1} \mathrm{~h}^{-1}\right)$ & & & & & & & & & & & & \\
\hline $\mathrm{PP}$ & $9.43 \mathrm{E}^{-07}$ & n.s. ${ }^{1}$ & $\mathrm{~B}^{2}$ & 3.35E-06 & n.s. & B & 3.31E-05 & n.s. & A & 3.89E-05 & n.s. & A \\
\hline PLA & $1.28 \mathrm{E}-05$ & & B & 8.68E-06 & & B & 1.47E-05 & & B & 4.11E-05 & & A \\
\hline BIO N.C. & 5.92E-06 & & B & 3.43E-05 & & $A B$ & 3.43E-05 & & $A B$ & 5.74E-05 & & $A$ \\
\hline $\mathrm{RRO}_{2}\left(\mathrm{ml} \mathrm{kg}^{-1} \mathrm{~h}^{-1}\right)$ & & & & & & & & & & & & \\
\hline $\mathrm{PP}$ & $1.74 \mathrm{E}-07$ & n.s. & B & 5.35E-07 & n.s. & B & $7.55 \mathrm{E}-06$ & n.s. & $A$ & $6.48 \mathrm{E}-06$ & n.s. & A \\
\hline PLA & 1.73E-06 & & B & 2.07E-06 & & $\mathrm{B}$ & 4.08E-06 & & A & 4.76E-06 & & A \\
\hline BIO N.C. & $1.48 \mathrm{E}-06$ & & N.S. & 6.06E-06 & & N.S. & 6.06E-06 & & N.S. & 8.12E-06 & & N.S. \\
\hline
\end{tabular}

${ }^{1}$ The means in a column followed by different letters are significantly different at $\mathrm{P} \leq 0.05$ according to Duncan's test. ${ }^{2}$ The means in a row followed by different letters are significantly different at $\mathrm{P} \leq 0.05$ according to Duncan's test 


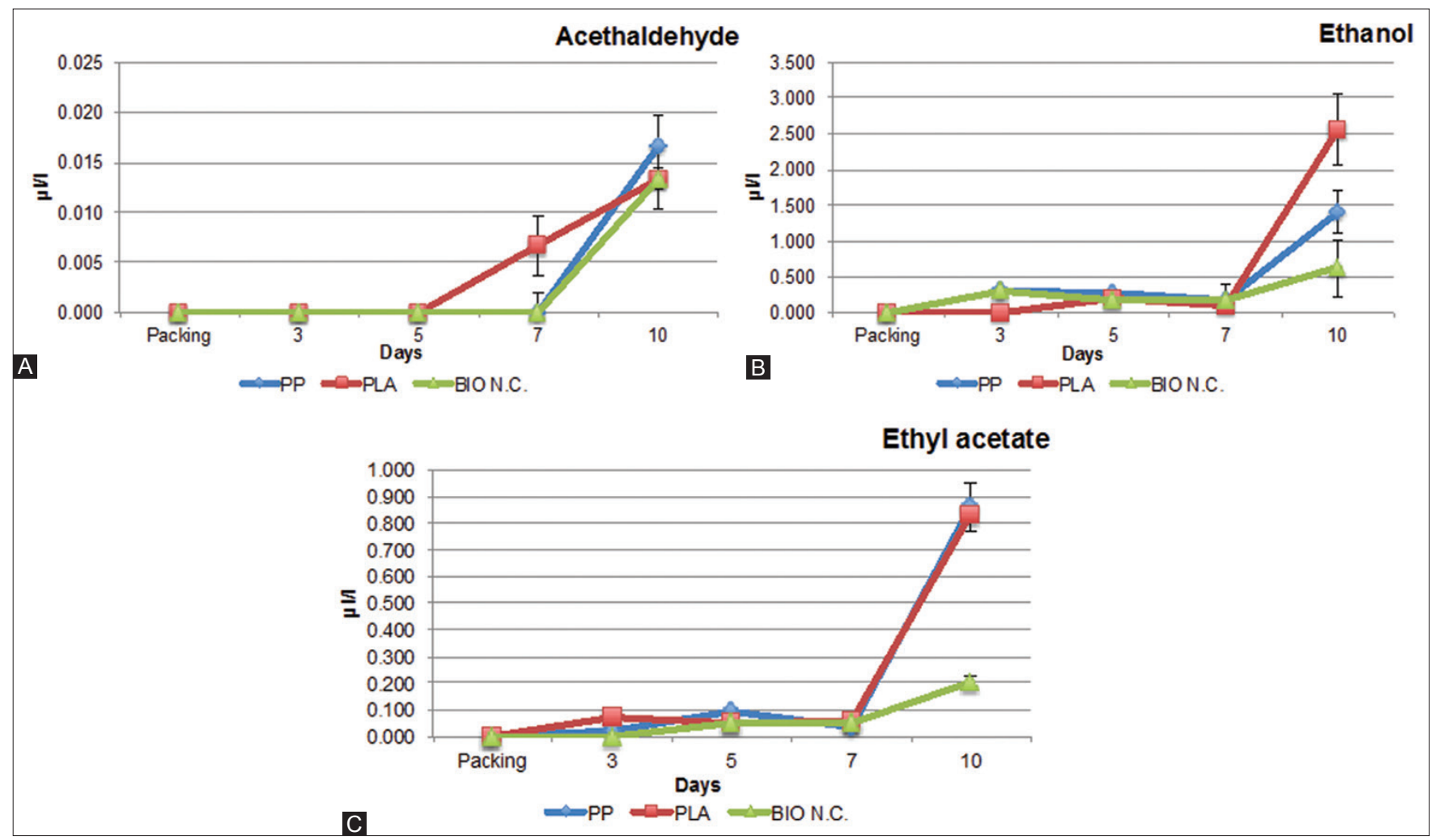

Fig 2. (A-C) Evolution of acethaldehyde, ethanol and ethyl acetate for the PP, PLA and BIO N.C. during all the storage time.

Table 2: Evolution of firmness (N), total solid soluble contents ( $\left.{ }^{\circ} \mathrm{Brix}\right)$ citric acid $(\%)$, color index $(\mathrm{Cl})$ and total polyphenols $\left(\mathrm{mg}_{\mathrm{GAE}} 100 \mathrm{~g}^{-1}\right)$ for PP, PLA and BIO N.C. films during all the storage

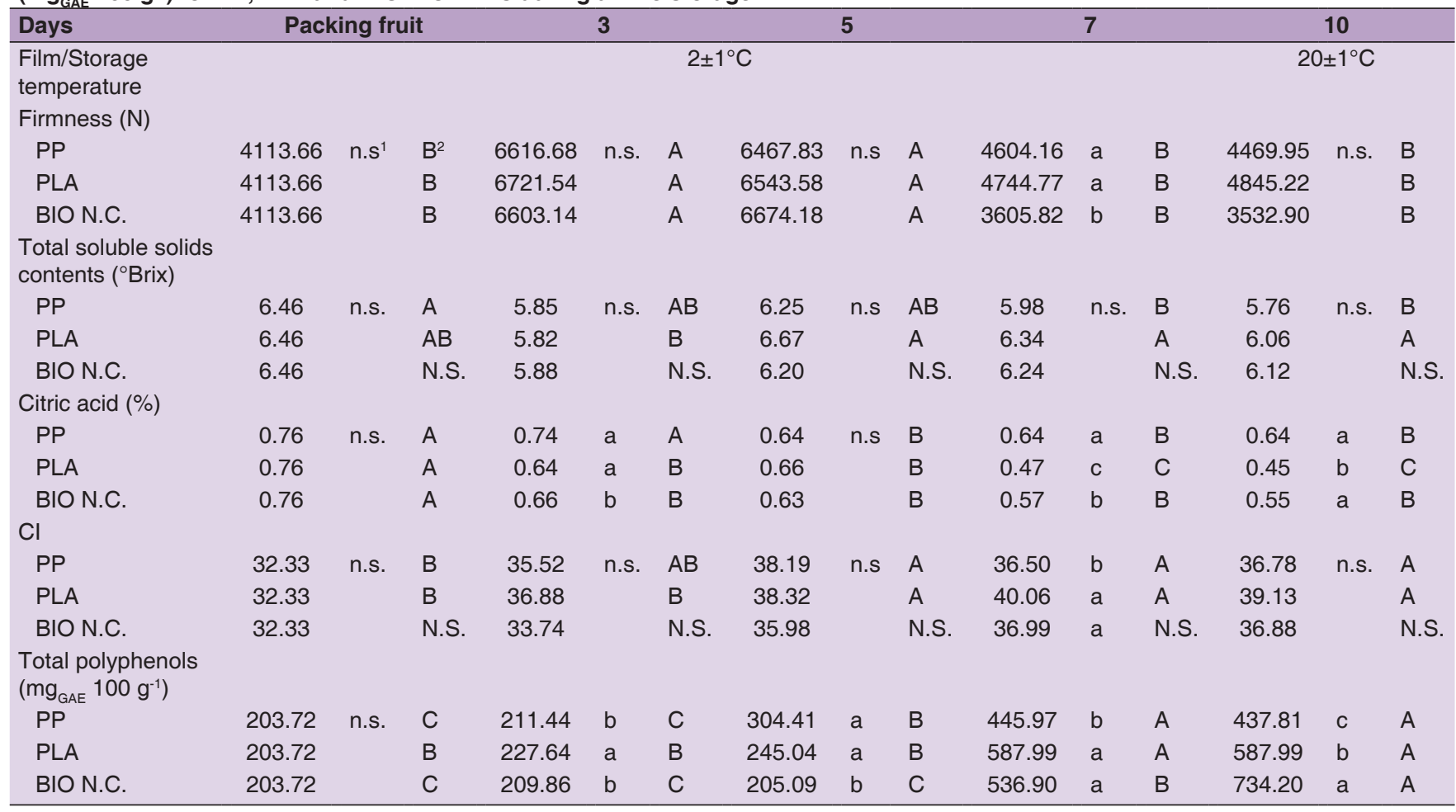

${ }^{1}$ The means in a column followed by different letters are significantly different at $\mathrm{P} \leq 0.05$ according to Duncan's test. ${ }^{2}$ The means in arow followed by different letters are significantly different at $\mathrm{P} \leq 0.05$ according to Duncan's test

of fresh tissue making them stronger (Paull, 1999). With the increase of the temperature to $20^{\circ} \mathrm{C}$ at 7 days all samples stored in MAPs significantly lost their turgor and firmness according to Luoto (1984). At the end of the 
storage time at the highest temperature (10 days) samples showed respectively less than 30\% (PP), 26\% (PLA) and $47 \%$ (BIO.N.C.) of their firmness if compared to values acquired at the end of the storage time at $2^{\circ} \mathrm{C}(5$ days). No statistically differences were observed among films for the most of control quality.

The initial TSSC was of $6.46^{\circ} \mathrm{Brix}$. No statistically differences were observed among samples for each control quality but a general decrease of values were showed for all films with the shift of the temperature beginning to 7 days up to the end of storage. The loss of TSSC was due to the increase in the respiration activity of strawberries during storage and the use of sugars as respiratory substrate.

The initial citric acid value was of $0.76 \%$. According to Caner et al. (2008) the reduction of acidity during storage is an indicator of fruit ripening. All samples showed this behavior. Already after 3 days of storage at $2^{\circ} \mathrm{C}$ all samples showed losses in the acidic content due the increasing of respiratory activity. Strawberries stored with the PLA Map have reduced deeply the citric content achieving the lowest value at the end of the storage time $(0.45 \%)$.

All samples showed an increase in the color index (CI) if compared to the packaging time (packing fruits) (32.33 CI). Statistically significantly differences were observed during the storage time for samples stored with the PP and the PLA film. The highest values were observed with the change of the temperature at 7 days up to end of storage and according with Martínez-Las Heras et al. (2016) it means that the ripe of strawberries go on.

The respiration of all sampled strawberries in fact affect the water loss content (data not showed) whose values influence deeply the skin color perception.

The total polyphenols measured at the packing fruit were $203.7225 \mathrm{mg}_{\mathrm{GAE}} 100^{-1} \mathrm{~g}$ according to previous works (Klopotek et al., 2005; Da Silva Pinto et al., 2008). Limited studies reported the changes in strawberry polyphenols in response to carbon dioxide treatments (Gil et al., 1997). The high $\mathrm{CO}_{2}$ concentrations achieved with the increase of the temperature during the storage time have resulted to a in destabilization of total polyphenols in all samples MAPs and increasing values were observed along all the storage time.

\section{Principal component analysis}

Principal component analysis was carried out on the correlation matrix produced from the maturity index and the quality parameters of strawberries stored in the green passive MAPs, previously measured. The Fig. 3 reports the 10 parameters and the relative weight for all the

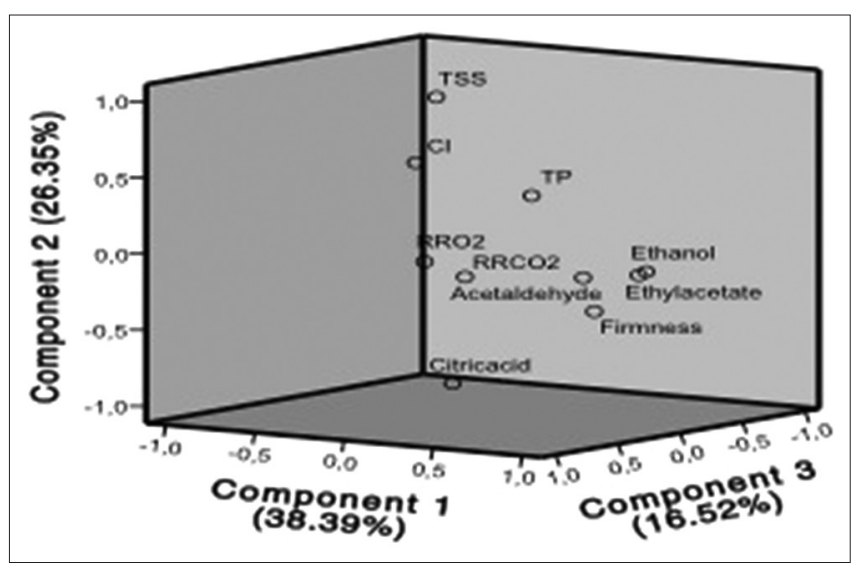

Fig 3. Principal componet analysis (PCA) for the respiration rate $\mathrm{CO}_{2}\left(\mathrm{ml} \mathrm{kg}^{-1} \mathrm{~h}^{-1}\right)$, respiration rate $\mathrm{O}_{2}\left(\mathrm{ml} \mathrm{kg}^{-1} \mathrm{~h}^{-1}\right)$, acethaldeyde $(\mu \mathrm{l} / \mathrm{l})$, ethanol $(\mu \mathrm{l} / \mathrm{l})$, ethyl acetate $(\mu \mathrm{l} / \mathrm{l})$, total solid soluble ( $\left.{ }^{\circ} \mathrm{Brix}\right)$, firmness $(\mathrm{N})$, color index, citric acid $(\%)$ and total polyphenols $\left(\mathrm{mgGAE}^{100-1} \mathrm{~g}\right)$.

components groups resulted (4). After the standardization of all data it was possible to evaluate the proportion of the cumulative percentage variance of each maturity index and the quality parameters. The cumulative variance contribution of all the principal component resulted was of $91 \%$ who contributed most the first (PC1) and second (PC2) principal components (respectively 38.39 $\%$ and $26.35 \%$ ). The PC1 largely depends by the off flavors (acetaldehyde, ethanol, ethyl acetate) developed during the storage and the firmness of strawberries; these parameters are positively correlated as indicators to explain the goodness of the influence of green passive MAP. A similar weight in the PC2 calculation are expressed by the total solid soluble content and the color index. (CI) to underline a strong pattern among the sweetness of strawberries and the color development of their tissues. The PC 3 that explains the $16.35 \%$ of the variance consider the $\mathrm{CO}_{2}$ and the $\mathrm{O}_{2}$ respiration rate of the fruits and their polyphenol content, that so appear mainly related among them. The lowest variance $(9.23 \%)$ is represented only by the citric acid.

\section{CONCLUSIONS}

The evaluation of off-flavors and the appearance of strawberries are the main criteria to evaluate the goodness of films used to store fruits with MAPs. The ability of the green films used in this study to manage the maturity of the strawberries cv. Portola is mainly affected by the storage temperature. With the shift of the temperature to $2^{\circ} \mathrm{C}$ to $20^{\circ} \mathrm{C}$ all the gaseous and quality maturity indices have been changed and the main differences in the performance among films were observed at the end of the storage time with the exception of the firmness of the pulp and the total soluble solid content. In fact no differences were observed among films about these quality parametres. 
The PLA films have developed the highest $\mathrm{CO}_{2}$ concentrations in the headspace gas composition of packages that affected the highest values of acetaldehyde, ethanol and ethyl acetate. Fruits wrapped with the PLA showed also the lowest acidic content and color index meanings that strawberry's ripening goes on. The BIO N.C. film due the highest $\mathrm{CO}_{2}$ respiration rate at the end of the storage caused the increase in the polyphenol content in strawberries but has maintained the lowest values in terms of volatiles monitored probably due to the highest permeability of the material (data not showed).

The PCA analysis showed some important differences among the quality parameters and maturity index analyzed to describe the behavior of the $\mathrm{cv}$. Portola during the storage under the MAP conditions evaluated.

However to improve the discussion of this study it would also be interesting to find out whether any correlation exists between the off-flavour score of strawberries and the consumer acceptability using a trained panel evaluation as reported in previous studies (Ke et al., 1991; Larsen and Watkins, 1995).

\section{ACKNOWLEDGEMENTS}

This work was conducted with the financial support of the Ministry of Economic Development-Industrial 2015, New Technologies for "Made in Italy"-Vivopack.

\section{Author's contributions}

Cristiana Peano designed the research, Briano Rossella collected data, interpreted results and wrote the paper, Giuggioli Nicole Roberta collaborated in the literature review and checked results. All authors read and approved the final manuscript, analyzed the data and participated jointly to the discussion. All authors have read and approved the final manuscript.

\section{Conflicts of interest}

The authors declare no conflict of interest

\section{REFERENCES}

Almenar, E., H. Samsudin, R. Auras, B. Harte and M. Rubino. 2008. Postharvest shelf life extension of blueberries using a biodegradable package. Food Chem. 110: 120-127.

Bermejo-Prada, A. and L. Otero. 2016. Effect of hyperbaric storage at room temperature on color degradation of strawberry juice. J. Food Eng. 169: 141-148.

Blanco-Díaz, M. T., A. Pérez-Vincent and R. Font. 2016. Quality of fresh cut zucchini as affected by cultivar, maturity processing and packaging. Packag. Technol. Sci. 29(7): 365-382.

Briano, R., N. R. Giuggioli, V. Girgenti and C. Peano. 2015. Biodegradable and compostable film and modified atmosphere packaging in postharvest supply chain of raspberry fruits ( $\mathrm{cV}$. Grandeur $^{\circledR}$ ). J. Food Process. Preserv. 39: 2061-2073.

Cagnon, T., C. Guillaume, V. Guillard and N. Gontard. 2013. Nanostructuring and microstructuring of materials from a single agropolymer for sustainable MAP preservation of fresh food. Packag. Technol. Sci. 26: 137-148.

Caner, C., M. S. Aday and M. Demir. 2008. Extending the quality of fresh strawberries by equilibrium modified atmosphere packaging. Eur. Food Res. Technol. 227(6): 1575-1583.

Cano, A. I., M. Cháfer, A. Chiralt and C. González-Martínez. 2015. Physical and microstructural properties of biodegradable films based on pea starch and PVA. J. Food Eng. 167: 59-64.

Da Silva Pinto, M., F. M. Lajolo and M. I. Genovese. 2008. Bioactive compounds and quantification of total ellagic acid in strawberries (Fragaria $x$ ananassa Duch.). Food Chem. 107(4): 1629-1635.

Fernandez-Trujillo, J. P., J. F. Nock and C. B. Watkins. 1999. Fermentative metabolism and organic acid concentrations in fruit of selected strawberry cultivars with different tolerance to carbon dioxide. J. Am. Soc. Hortic. Sci. 124: 696-701.

Gil, M. I., D. M. Holcroft and A. A. Kader. 1997. Changes in strawberry anthocyanins and other polyphenols in response to carbon dioxide treatments. J. Agric. Food Chem. 45(5): 1662-1667.

Giuggioli, N. R., R. Briano, C. Baudino and C. Peano. 2015. Effects of packaging and storage conditions on quality and volatile compounds of raspberry fruits. CyTA J. Food. 13: 512-521.

Hertog, M. L. A., H. A. M. Boerrigter, G. J. P. Van Den Boogaard, L. M. M. Tijskens and A. C. R. Van Schaik. 1999. Predicting keeping quality of strawberries ( $c v$. 'Elsanta') packed under modified atmospheres: An integrated model approach. Postharvest Biol. Technol. 15(1): 1-12.

Jiménez-Cuesta, M. J., J. Cuquerella and J. M. Martínez-Jávega. 1981. Determination of a color index for citrus fruit degreening. Proc. Int. Soc. Citric. 2: 750-753.

Kader, A. A. 1991. Quality and its maintenance in relation to the postharvest physiology of strawberry. In: Dale, A. and J. J. Luby (Eds.), The Strawberry into the $21^{\text {st }}$, Timber Press, Portland, Oregon, USA, pp. 145-152.

Kader, A. A. and D. M. Barrett. 2005. Classification, composition of fruits, and postharvest maintenance of quality. In: Barrett, D. M., L. Somogyi and H. Ramaswamy (Eds.), Processing Fruits, $2^{\text {nd }}$ ed. CRC Press, Boca Raton, Florida, USA, pp. 3-22.

Ke, D., L. Goldstein, M. O'Mahony and A. A. Kader. 1991. Effects of short-term exposure to low $\mathrm{O}_{2}$ and high $\mathrm{CO}_{2}$ atmospheres on quality attributes of strawberries. J. Food Sci. 56(1): 50-54.

Ke, D., E. Yahia, M. Mateos and A. A. Kader. 1994. Ethanolic fermentation of Bartlett' pears as influenced by ripening stage and atmospheric composition. J. Am. Soc. Hort. Sci. 119(5): 976-982.

Kennedy, R. A., M. E. Rumpho and T. C. Fox. 1992. Anaerobic metabolism in plants. Plant Physiol. 100: 1-6.

Klopotek, Y., K. Otto and V. Böhm. 2005. Processing strawberries to different products alters contents of vitamin C, total phenolic, total anthocyanins, and antioxidant capacity. J. Agric. Food Chem. 53(14): 5640-5646.

Larsen, M. and C. B. Watkins. 1995. Firmness and concentrations of acetaldehyde, ethyl acetate and ethanol in strawberries stored in controlled and modified atmospheres. Postharvest Biol. Technol. 5: 39-45.

Li, C. and A. A. Kader. 1989. Residual effects of controlled atmospheres on postharvest physiology and quality of strawberries. J. Am. Soc. Hort. Sci. 114: 629-634.

Luoto, L. 1984. Strawberry quality: Effects of handling, packaging and 
storage on shelf-life. Acta Hortic. 157: 79-82.

Mangaraj, S., T. K. Goswami and P. V. Mahajan. 2009. Applications of plastic films for modified atmosphere packaging of fruits and vegetables: A review. Food Eng. Rev. 1: 133-158.

Martínez-Las, H., J. C. Ramigo-Sánchez, A. Heredia, M. L. Castelló and A. Andrés. 2016. Influence of preharvest treatments to reduce the seasonality of persimmon production on color, texture and antioxidant properties during storage. CyTA J. Food. 14(2): 333-339.

Mistriotis, A., D. Briassoulis, A. Giannoulis and S. D'Aquino. 2016. Design of biodegradable bio-based equilibrium modified atmosphere packaging (EMAP) for fresh fruits and vegetables by using micro-perforated poly-lactic acid (PLA) films. Postharvest Biol. Technol. 111: 380-389.

Nielsen, T. J. and I. M. Jagerstad. 1994. Flavor scalping by food packaging. Trends. Food Sci. Technol. 5: 353-356.

Paull, R. E. 1999. Effect of temperature and relative humidity on fresh commodity quality. Postharvest Biol. Technol. 15: 263-277.

Pelayo, C., S. E. Ebeler and A. A. Kader. 2003. Postharvest life and flavor quality of three strawberry cultivars kept at $5^{\circ} \mathrm{C}$ in air or air $20 \mathrm{kPa} \mathrm{CO}$. Postharvest Biol. Technol. 27: 171-118.

Pesis, E. and I. Avissar. 1990. Effect of postharvest application of acetaldehyde vapour on strawberry decay, taste and certain volatiles. J. Sci. Food Agric. 52: 377-385.

Ponce-Valadez, M. and C. B. Watkins. 2008. Fermentation and malate metabolism in response to elevated $\mathrm{CO}_{2}$ concentrations in two strawberry cultivars. Physiol. Plant. 134: 121-133.

Renault, P., L. Houal, G. Jacquemin, and Y. Chambroy. 1994. Gas exchange in modified atmosphere packaging. 2. Experimental results with strawberries. Int. J. Food Sci. Technol. 29: 379-394.

Russel, L. F., D. I. LeBlanc, K. B. McRae and D. A. J. Ryan. 2009. Losses of vitamin $\mathrm{C}$ from fresh strawberries in a commercial supply chain. Int. J. Food Sci. Techol. 44: 820-828.
Sajilata, M. G., K. Savitha, R. S. Singhal and V. R. Kanetkar. 2007. Scalping of flavors in packaged foods. Compr. Food Sci. Food Saf. 6: 17-35.

Shaw, P. E., R. D. Carter, M. G. Moshonas and G. Sadler. 1990 Controlled atmosphere storage of oranges to enhance aqueous essence and essence oil. J. Food Sci. 55: 1617-1619.

Slinkard, K. and V. L. Singleton. 1977. Total phenol analysis: Automation and comparison with manual methods. Am. J. Enol. Vitic. 28: 49-55.

Soltani, M., R. Alimardani, H. Mobli, H. Mohtasebi and S. S. Modi. 2015. Atmosphere packaging: A progressive technology for shelf-life extension of fruits and vegetables. J. Appl. Packag. Res. 3(7): 33-59.

Sucan, M. K. 2004. Identifying and preventing off-flavors. Food Technol. 58(11): 36-40.

Talasila, P. C., K. V. Chau and J. K. Brecht. 1995. Modified atmosphere packaging under varying surrounding temperature. Trans. ASAE. 38: 869-876.

Wani, A. A., P. Singh, K. Gul, M. H. Wani and H. C. Langowski. 2014. Review sweet cherry (Prunus avium): Critical factors affecting the composition and shelf life. Food Packag. Shelf Life. 1: 6-9.

Watkins, C. B., J. E. Manzano-Mendez, J. F. Nock, J. Z. Zhang, J. Z. Zhang and K. F. Maloney. 1991. Cultivar variation in response of strawberry fruit to high carbon dioxide treatments. J. Food Sci. 10: 501-890.

Xiaotang, Y., S. Jun, F. Sherry, P. Xuequn and Z. Zhaoqi. 2011. Effect of high temperature on color, chlorophyll fluorescence and volatile biosynthesis in green-ripe banana fruit. Postharvest Biol. Technol. 62: 246-257.

Zang, M., X. Meng, B. Bhandari, Z. Fag and H. Chen. 2015. Recent application of modified atmosphere packaging (MAP) in fresh and fresh-cut foods. Food Rev. Int. 31: 172-119. 